\title{
Coastal States and MPAs in ABNJ: Ensuring Consistency with the LOSC
}

\author{
Alex G. Oude Elferink \\ Netherlands Institute for the Law of the Sea, Utrecht Centre for Oceans, \\ Water and Sustainability Law, Utrecht University, K.G. Jebsen Centre for the \\ Law of the Sea, UiT, The Arctic University of Norway
}

\begin{abstract}
To address the question how a future instrument for areas beyond national jurisdiction $(\mathrm{ABNJ})$ might give consideration to the rights and obligations of coastal States and other States in establishing marine protected areas (MPAs) in ABNJ, the current article discusses the options that have been tabled in this respect in the preparatory meetings for the intergovernmental conference that will be negotiating that instrument. In considering the current legal framework, the focus is on the United Nations Convention on the Law of the Sea (LOSC), as the new instrument is to be elaborated under the LOSC and is required to be fully consistent with it. The article analyses the relevant practice of four specific regions that have established MPAs in ABNJ. The article concludes that due regard is fundamental in addressing interactions between coastal States and other States and considers some options to provide it with specific content.
\end{abstract}

\section{Keywords}

areas beyond national jurisdiction $(\mathrm{ABNJ})$ - high seas - due regard - coastal States adjacency - marine protected areas (MPA s) - international legally binding instrument (ILBI) - biological diversity of areas beyond national jurisdiction (BBNJ) - continental shelf - exclusive economic zone

(C) ALEX G. OUDE ELFERINK, 2019 | DOI:10.1163/9789004391703_004

This is an open access chapter distributed under the terms of the prevailing CC-BY-NC license at the time of publication. 
The international community has committed itself to protecting at least 10 percent of marine and coastal areas by the establishment of protected areas., ${ }^{*} 1$ Meeting this target implies that States will also have to designate marine protected areas (MPAS) ${ }^{2}$ in areas beyond national jurisdiction $(\mathrm{ABNJ}) .^{3}$ This topic actually has been under consideration during the discussions on an international legally binding instrument (ILBI) under the United Nations Convention on the Law of the Sea on the conservation and sustainable use of marine biological diversity of areas beyond national jurisdiction that have been taking place at the United Nations. One of the controversial issues is how the rights of coastal States over their maritime zones should be taken into consideration in this connection. Due to, among others, the transboundary effects of activities in the marine environment and the fact that areas requiring protection may straddle ABNJ and coastal State zones, there is an obvious need to address this issue. As these considerations indicate, this may not only be a matter of giving

* Principal Investigator Nereus Program; Predicting Future Oceans; The Nippon Foundation. This article originates in the presentation MPAs adjacent to or adjoining areas under national jurisdiction: legal and practical challenges I gave at the вв tion and sustainable use of marine biological diversity beyond areas of national jurisdiction through a new legally binding instrument under UNCLOS convened by the Government of Portugal and the High Seas Alliance in Lisbon from 1 to 3 March 2017. I would like to thank the organizers for providing me this opportunity and the participants at the workshop for their feedback. I would like to thank Rui Chang for her research in preparation of this article and her contribution to preparing a first draft outline and Catherine Blanchard, Erik Molenaar, Rui Chang and two anonymous reviewers for commenting on a draft version of this article.

1 Aichi Targets, Target 11; available at https://www.cbd.int/sp/targets/default.shtml.

2 There is no generally accepted definition of the term MPA. For the purposes of this article it is not necessary to further address this matter.

3 If no MPAs were to be designated in ABNJ, coastal States would have to designate up to 20 per cent of their maritime zones as MPAs to meet Aichi Target 11. Moreover, to reach a comprehensive coverage of all types of ecosystems, MPAs have to include areas within and beyond national jurisdiction. Aichi Target 11 actually refers to "protected areas and other effective area-based conservation measures". The current discussions at the United Nations concerning an International legally binding instrument under the United Nations Convention on the Law of the Sea on the conservation and sustainable use of marine biological diversity of areas beyond national jurisdiction (ILBI) similarly refer to, e.g., "measures such as areabased management tools [Авмтs], including marine protected areas" (General Assembly Resolution A/RES/72/249 - International legally binding instrument under the United Nations Convention on the Law of the Sea on the conservation and sustainable use of marine biological diversity of areas beyond national jurisdiction (available at http://www.un.org/ en/ga/search/view_doc.asp?symbol=A/RES/72/249), para. 2). The current article only uses the term MPA and focusses on practice in relation to MPAs. This focus does not affect the outcome of the analysis contained in this article. 
consideration to the rights of coastal States. The obligations of coastal States to protect and preserve the marine environment may require them to consider how the need to protect the marine environment in $\mathrm{ABNJ}$, including MPAS in $\mathrm{ABNJ}$, may affect the exercise of their rights as coastal States.

To address the question of how a future ILBI might give consideration to the rights and obligations of coastal States and other States in establishing MPAs in $A B N J$, the current article starts with a discussion of the options that have been tabled in this respect in the preparatory meetings leading up to the intergovernmental conference that has been charged with negotiating the ILBI. Next, the article considers what the current legal framework has to say on this matter. This discussion focusses on the United Nations Convention on the Law of the Sea (LOSC). ${ }^{4}$ The LOSC is generally recognized as the fundamental jurisdictional framework for oceans governance and the ILBI is to be elaborated under the Losc. ${ }^{5}$ A further section analyses the practice of four specific regions in order to determine how that practice has given consideration to the rights and obligations of coastal States and other States in establishing MPAs in ABNJ. A final section offers some concluding thoughts.

\section{2 Discussions at the Preparatory Committee}

Between 2016 and 2017 a Preparatory Committee (PrepCom), which had been established by the United Nations General Assembly, considered the negotiation of the ILBI at an intergovernmental conference. ${ }^{6}$ During the discussions at the PrepCom, the possible role of coastal States in designating and managing MPAs proved to be one of the controversial issues. An overview of different options was provided by a non-paper prepared by the PrepCom Chair. ${ }^{7}$ Under

4 United Nations Convention on the Law of the Sea (Montego Bay, 10 December 1982, in force 16 November 1994) 1833 UNTS 396.

5 For the relationship between the ILBI and the LOSC see also text below at (nn 28, 29).

6 General Assembly Resolution A/69/292 of 19 June 2015 (available at http://daccess-ods .un.org/access.nsf/Get?Open\&DS=A/RES/69/292\&Lang=E).

7 Chair's streamlined non-paper on elements of a draft text of an international legally binding instrument under the United Nations Convention on the Law of the Sea on the conservation and sustainable use of marine biological diversity of areas beyond national jurisdiction (Document of the fourth session of the PrepCom (10-21 July 2017) (available at http://www .un.org/Depts/los/biodiversity/prepcom.htm). As the non-paper observes, the document: 'provides a compilation of the ideas and proposals put forward by delegations without consideration for the level of support for these ideas and proposals. The inclusion of ideas and proposals in this document does not imply agreement to, or convergence of views on, such ideas and proposals among delegations' (ibid., p. 1). 
the heading of 'General principles and approaches', the non-paper listed the following items dealing with giving consideration to the rights and obligations of coastal States (and other States) in establishing M PAs in ABNJ:

- Due regard for the rights of others.

- Respect for the rights of coastal States over all areas under their national jurisdiction, including their continental shelves beyond 200 nautical miles where applicable.

- Respect for the sovereignty and territorial integrity of coastal States.

- Compatibility.

- Adjacency and requirement to consult adjacent States. ${ }^{8}$

- Recognition of the role of adjacent coastal States as well as other States. ${ }^{9}$

As the report of the fourth session of the PrepCom to the General Assembly indicates, this matter, like most matters concerning the ILBI, has been left for further consideration by the future intergovernmental conference. The report contains Recommendations to the General Assembly, which are divided into sections A and B. These include elements that may be considered in the further preparation of the ILBI. ${ }^{10}$ As the report states, "Section A includes nonexclusive elements that generated convergence among most delegations" and "[b]oth sections are without prejudice to the positions of States during the negotiations"."1 The text in Section A dealing with the issue of coastal States in relation to MPAS in ABNJ illustrates the high level of abstraction of the "convergence among most delegations". Under the heading "Relationship to measures under relevant instruments, frameworks and bodies" it is provided that the text of an ILBI "would also address the relationship between measures under the instrument and those established by adjacent coastal States, including issues of compatibility, without prejudice to the rights of coastal States". ${ }^{2}$ In the envisaged process of consultation and assessment of proposals on MPAs,

8 Next to the term 'adjacent' the term 'adjoining' has also been used in this context. The current article will use the term 'adjacent' throughout.

9 Chair's streamlined non-paper (n 7$)$ at p. 11, para. 24. The non-paper's section on AвмTs and MPAs moreover includes references to the rights of coastal States, including the need to secure the agreement of coastal States adjacent to ABNJ in creating ABMTs (ibid., p. 23, para. 107; see also ibid., p. 24, paras 115-116 and p. 26, para. 131). For a further consideration of this list of items see below, current section.

10 Report of the Preparatory Committee established by General Assembly Resolution 69/292: Development of an international legally binding instrument under the United Nations Convention on the Law of the Sea on the conservation and sustainable use of marine biological diversity of areas beyond national jurisdiction (UN Doc. A/AC.287/2017/PC.4/2) (available at http://www.un.org/Depts/los/biodiversity/prepcom.htm), p. 7, para. 38 .

11 Ibid.

12 Ibid., p. 11, para. 4.2. 
reference is made to a large number of interested parties, in which adjacent coastal States are merely included as a subcategory of all States..$^{13}$ As regards decision-making on issues concerning M PAs, the options are completely open, as the text states that it remains to be decided "how decisions [...] would be made, including who would make the decision and on what basis". ${ }^{14}$ The text envisages that in this connection it would have to be considered how to involve coastal States adjacent to a proposed MPA. ${ }^{15}$ Although Section A thus recognizes the need for further consideration of the role of adjacent coastal States, it does not imply any recognition of a special role for coastal States in this respect.

The list of options to deal with the rights of other States contained in the Chair's non-paper as cited above indicates the range of alternatives that have been suggested to address this matter. The concepts of "due regard" and "compatibility" do not imply a preferential role for either other States and other actors dealing with MPAS in ABNJ or for adjacent coastal States. The implications of these concepts to a large extent would have to be determined in light of the circumstances of the particular case. ${ }^{16}$ The references to "respect for the rights", and the "sovereignty and territorial integrity of coastal States" imply a prioritization of the coastal State. The concept of "adjacency", with only a reference to consultation with the coastal State, would in comparison at first sight seem to suggest a limited role for coastal States.

Some further understanding of the various concepts that have been advanced in connection with possible interactions between MPAs in ABNJ and zones under coastal State jurisdiction may be gleaned from documents that States have submitted to the PrepCom and their statements during the PrepCom meetings. References to adjacency and the adjacent coastal State in general advance a prioritized coastal State position, ${ }^{17}$ without providing

13 Ibid., p. 12, para. 4.3.2, sub ii.

14 Ibid., sub iii.

15 Ibid.

16 See also text below after ( $\left.n_{56}\right)$; and at ( $n_{72}$ ) et seq.

17 For a detailed discussion of the concept of "adjacency", which, however, does not necessarily reflect the views of States at the PrepCom, see DC Dunn, G Ortuño Crespo, M Vierros, D Freestone, E Rosenthal, S Roady, A Alberini, A-L Harrison, A Cisneros, JW Moore, MR Sloat, Y Ota, R Caddell, and PN Halpin, Adjacency: How legal precedent, ecological connectivity, and traditional knowledge inform our understanding of proximity (Policy Brief UN PrepCom 3; Nereus Scientific \& Technical Briefs on ABNJ series) (available at https:// www.researchgate.net/publication/31884216o_Adjacency_How_legal_precedent_ecological_connectivity_and_Traditional_Knowledge_inform_our_understanding_of_proximity_POLICY_BRIEF_-_UN_PrepCom_3). Interestingly, the brief includes no discussion of the concept of "due regard". In relation to adjacency, the brief notes that: 'While the 
much detail as to its precise content and implications. At the fourth session of the PrepCom, the Pacific small island developing States "requested including the adjacency principle to address the interests of adjacent coastal states". ${ }^{18}$ The Cook Islands further commented on this point to the effect that "activities in ABNJ should not impact activities within national jurisdiction". ${ }^{19}$ During the third session of the PrepCom, States also referred to the need for consent of the adjacent coastal State in taking decisions in relation to MPAs in ABNJ. ${ }^{20}$

legal definition of adjacency addresses geographic proximity, the ecological implications of adjacency involve oceanographic and ecological connectivity. An area adjacent to a national jurisdiction may be equally ecologically or biologically connected to areas on the other side of an ocean basin through oceanographic or migratory connectivity' (ibid., p. 2). The policy brief further argues for: 'granting coastal States greater influence over management of those ABNJ resources to which they lie adjacent. Under this approach, those qualified adjacent states would be recognized as having the primary responsibility to coordinate with existing sectoral and regional organizations to become the leading architects of new regional conservation agreements' (ibid., pp. 1-2). The brief subsequently also recognizes that this approach would imply 'extending the rights of coastal States' (ibid., p. 9). It may be questioned whether oceanographic and ecological connectivity are best addressed through the concept of adjacency. Another approach could, for instance, consist of an adaptation of the concept of "Range State" contained in the Convention on the Conservation of Migratory Species of Wild Animals (CMS) (Bonn, 23 June 1979; in force 1 November 1983; 1651 UNTS 355), which would not require an adaptation of the jurisdictional framework contained in the LOsC. The cMs requires Range States of migratory species to cooperate to reach a favorable conservation status of migratory species. Article $1(1)(h)$ of the cms defines the term "Range State": 'in relation to a particular migratory species means any State [...] that exercises jurisdiction over any part of the range of that migratory species, or a State, flag vessels of which are engaged outside national jurisdictional limits in taking that migratory species.' In the context of an ILBI, a concept similar to that of "Range State" could include all States under whose jurisdiction or control activities and processes are taking place that affect an MPA. All those States could be included in the development of instruments/programs/measures aimed at protecting or restoring the biodiversity and ecosystem of the MPA.

18 Summary of the Fourth Session of the Preparatory Committee on Marine Biodiversity Beyond Areas of National Jurisdiction: 10-21 July 2017 (Earth Negotiations Bulletin Vol. 25 No. 141), p. 8.

19 Ibid. See also Summary of the First Session of the Preparatory Committee on Marine Biodiversity Beyond Areas of National Jurisdiction: 28 March-8 April 2016 (Earth Negotiations Bulletin Vol. 25 No. 106), p. 4 (statement of the Federated States of Micronesia). See, e.g., Summary of the Third Session of the Preparatory Committee on Marine Biodiversity Beyond Areas of National Jurisdiction: 27 March-7 April 2017 (Earth Negotiations Bulletin Vol. 25 No. 129), pp. 5-7 (statements of Fiji and Mauritius). In some other instances, references to the adjacent coastal State are less explicit. For instance, a document submitted by Fiji refers to the need for cooperation (see, e.g., Fiji's Submission for вввл PrepCom (available at http://www.un.org/depts/los/biodiversity/prepcom files/rolling_comp/Fiji.pdf), para. 45), whereas New Zealand argued for the "[re]cognition of the role of adjacent coastal states as well as other states" (Preparatory Committee 
The concept of "compatibility" has been invoked by States that also support the concept of "adjacency". ${ }^{21}$ In this connection, reference has been made to Article 7 of the Fish Stocks Agreement (FSA), ${ }^{22}$ which elaborates the concept of "compatibility" in relation to straddling and highly migratory fish stocks. ${ }^{23}$ As has been pointed out by the Pacific small island developing States, Article 7 specifically requires that measures for the high seas "do not undermine the effectiveness" of measures adopted by the coastal State. ${ }^{24}$

The concept of "due regard" has been juxtaposed to that of "adjacency". At the fourth session of the PrepCom, China, supported by the US, noted that "adjacency is not enshrined in [the LOsC and] [...] proposed "due regard" for coastal states' rights". ${ }^{25}$ The concept of "adjacency" has also been explicitly opposed by Singapore, the Republic of Korea and Switzerland. ${ }^{26}$ Support for the concept of "due regard" in relation to the rights of coastal States has also been expressed by the European Union and its Member States. ${ }^{27}$ The documents submitted to the PrepCom and statements made during its meetings do not shed any further light on the content of the concepts of "respect for the rights of coastal States over their maritime zones" and that of "respect for the sovereignty and territorial integrity of coastal States".

on Conservation and Sustainable Use of Marine Biological Diversity of Areas Beyond National Jurisdiction; New Zealand Submission; December 2016) (available at http:// www.un.org/depts/los/biodiversity/prepcom_files/rolling_comp/New_Zealand.pdf) p. 3).

21 See Psids Submission to the Second Meeting of the Preparatory Committee for the Development of an international legally binding instrument under the United Nations Convention on the Law of the Sea on the conservation and sustainable use of marine biological diversity of areas beyond national jurisdiction (ввNJ PrepCom); August 2016 (available at http://www.un.org/depts/los/biodiversity/prepcom_files/rolling_comp/ PSIDS_second.pdf), p. 3; Summary of the Third Session (n 2o) at p. 7 (statement of Chile). Agreement for the Implementation of the Provisions of the United Nations Convention on the Law of the Sea of 10 December 1982 relating to the Conservation and Management of Straddling Fish Stocks and Highly Migratory Fish Stocks (New York, 4 August 1995, in force 11 December 2001) 2167 UNTS 3.

23 Psids Submission (n 21), p. 3. For a further discussion of the concept of "compatibility" see text infra, after ( $\left.\mathrm{n}_{5} 6\right)$.

24 Psids Submission ( $\mathrm{n}$ 21). The Pacific small islands developing States in a similar vein invoked para. 199 of the International Tribunal for the Law of the Sea's (ITLOS) advisory opinion of 2 April 2015 in Request for an advisory opinion submitted by the Sub-Regional Fisheries Commission (SRFC) (ITLOS Reports 2015, p. 4) as the basis for cooperation (PSIDS Submission (n 21). Para. 199 of the opinion limits itself to referring to Article 63 of the LOSC, which has been further elaborated in Article 7 of the FSA.

25 Summary of the Fourth Session (n 18) at p. 8.

26 Ibid.

27 Written Submission of the EU and its Member States; Cross-cutting issues; 5 December 2016 (available at http://www.un.org/depts/los/biodiversity/prepcom_files/rolling_comp/ European\%2oUnion-cross-cutting_issues.pdf), p. 3 . 


\section{Balancing the Rights and Obligations of Coastal States and Other States under Current International Law}

\subsection{The Establishment of MPAs in ABNJ}

In view of the large measure of uncertainty surrounding the various terms that have been introduced at the PrepCom for defining the nexus between coastal States, other States and MPAs in ABNJ, it stands to reason to have a closer look at how this nexus has been conceptualized in the LOsc. This approach is in particular justified by the language included in the General Assembly Resolution convening the intergovernmental conference that is to negotiate the ILBI. ${ }^{28}$ The Resolution provides that "the work and results of the conference should be fully consistent with the provisions of the United Nations Convention on the Law of the Sea". 29

Before considering this matter, it is required to briefly consider the legal basis in the LOSC and the Convention on Biological Diversity (СВD) for designating and managing MPAs. ${ }^{30}$ This is explained by the fact that the consideration of the role of coastal States in relation to MPAs in ABNJ has to be assessed in the light of that legal basis. Article 194(5) of the LOsC, which has a spatial focus, provides a basis for the designation of MPAs. ${ }^{31}$ The Article does not explicitly

28 General Assembly Resolution A/RES/72/249 (n 3) at para. 1.

29 Ibid., para. 8. The General Assembly Resolution that set up the PrepCom did not include this specific reference to the Convention, but provided that the PrepCom process "should not undermine existing relevant legal instruments and frameworks and relevant global, regional and sectoral bodies" (General Assembly Resolution A/69/292 (n 6) at para. 3). Identical wording is included in Resolution $\mathrm{A} / 72 / 249$ setting up the intergovernmental conference (Resolution A/72/249 (n 3) at para. 7). Although the implications of the terms "fully consistent" and "not undermine" are not completely clear, it should be assumed that being fully consistent with an instrument sets a higher threshold than not undermining an instrument (see also C Blanchard "When "Not Undermining" Undermines The вBNJ Process Possible Effects of the "Not Undermining" Clause on the Upcoming Legally Binding Instrument' (paper presented at the Law of the Sea Interest Group of the 2017 Annual Conference of the European Society of International Law; on file with the author). For instance, the online Merriam-Webster Dictionary (https://www.merriam -webster.com/dictionary) defines the term consistent as "marked by harmony, regularity, or steady continuity; free from variation or contradiction [...]; marked by agreement" and defines the term undermine in terms of weakening something or someone.

30 Convention on Biological Diversity (Rio de Janeiro, 5 June 1992, in force 29 December 1993) (1992) 31 International Legal Materials 818.

31 Article 194(5) reads: 'The measures taken in accordance with this Part shall include those necessary to protect and preserve rare or fragile ecosystems as well as the habitat of depleted, threatened or endangered species and other forms of marine life.' For a further elaboration of this argument concerning Article 194(5), see EJ Molenaar and AG Oude Elferink, 'Marine protected areas in areas beyond national jurisdiction-The pioneering efforts under the OSPAR Convention' (2009) 5 Utrecht Law Review $5^{-20}$ at pp. 9-10. 
identify specific States that are responsible for taking the measures it may require, but it does refer to the "measures taken in accordance with [Part XII]" of the Convention. Part XII contains provisions that are directed at all States and at specific categories of States, such as flag States, port States and coastal States. Three points may be noted in this connection. First, Part XII stresses the importance of cooperation. ${ }^{32}$ Article 197 specifically refers to cooperation on a global or regional basis and, by including the requirement that such cooperation has to take "into account characteristic regional features", emphasizes the importance of cooperation at the regional level. Second, the focus of Part XII on measures for the prevention, reduction and control of pollution ${ }^{33}$ indicates that States that are involved in activities in ABNJ also have a primary responsibility in taking such measures in relation to MPAs in ABNJ. ${ }^{34}$ Third, Part XII also addresses the transboundary impacts of pollution. The relevant provisions in this connection impose obligations on the States under whose jurisdiction or control the activities concerned take place. That consideration also applies to coastal States in relation to MPAs in ABNJ.

The CBD, which is the other global instrument with most relevance to MPAs in ABNJ, provides that it is applicable to Parties "[i]n the case of processes and activities, regardless of where their effects occur, carried out under its jurisdiction or control". 35 That provision is also applicable in ABNJ. Article 5 of the СBD requires the Parties to cooperate in respect of $\mathrm{ABNJ}$ "for the conservation and sustainable use of biological diversity". ${ }^{36}$ As has been argued by Drankier, Article 5 facilitates implementation of Article 8 of the CBD on in situ conservation, including through the establishment of MPAs, which is primarily targeted at individual States. She submits that this is of particular significance for dealing with MPAs in ABNJ. ${ }^{37}$

Taken together, the above provisions of the LOSC and the CBD indicate that the primary responsibility for dealing with MPAs in ABNJ rests on States under whose jurisdiction or control activities affecting biodiversity in $\mathrm{ABNJ}$ take

32 See, e.g., LosC, Articles 194(1), 202 and 207-212.

33 See, e.g. ibid., Articles 194(1) and 196(1).

34 See also Molenaar and Oude Elferink (n 31) at p. 9.

$35 \mathrm{CBD}$, Article 4. Article 4 further provides that this is "[s]ubject to the rights of other States". The CвD does not refer to the rights of adjacent coastal States in relation to ABNJ. Article 22 of the СвD, on the relationship to other agreements, implies that these rights are primarily defined in the LOsC.

36 Article 5 of the CвD does not contain an explicit reference to regional cooperation or regional characteristics similar to that contained in Article 197 of the Losc. Article 5 refers to direct cooperation and cooperation through competent international organizations.

37 P Drankier, 'Marine Protected Areas in Areas beyond National Jurisdiction' (2012) 27 International Journal of Marine and Coastal Law 291-350 at p. 297. 
place. Cooperation is a key element in this respect. These provisions do not suggest the existence of a specific competence for adjacent coastal States in dealing with MPAs in ABNJ. ${ }^{38}$ This should not be taken to imply that the rights and duties of coastal States should not be taken into account in this regard. This requires a further consideration of the obligations of States in exercising jurisdiction or control over activities in ABNJ.

\subsection{The Rights of Coastal States and Other States in ABNJ}

The LOSC contains provisions that deal with the relationship between the competing rights and obligations of States in ABNJ and possible linkages with coastal States. Article 87 requires States to exercise their high seas freedoms "with due regard for the interests of other States in their exercise of the freedom of the high seas" ${ }^{39}$ Article 87 does not refer to due regard for the rights of the coastal State in its maritime zones. ${ }^{40}$ However, it is submitted that a "due regard" requirement also applies in this instance. Four arguments may be advanced to support this position. First, Article $5^{8}$ of the LOsc, which deals with the rights and duties of other States in the exclusive economic zone (EEZ), provides that the high seas freedoms those States enjoy in the EEZ shall be exercised with "due regard to the rights and duties of the coastal State". ${ }^{41}$ It would be curious if this "due regard" obligation in exercising a high seas freedom like navigation would cease to be applicable the moment a ship crosses the 200-nautical-mile limit and continues its voyage on the high seas. The same argument applies by analogy to any other activity taking place in the marine environment. Second, Part V of the Convention on the EEZ requires the coastal State to "have due regard to the rights and duties of other States". 42 Unlike the "due regard" provision of Article 58 , this provision is not limited to the area of the EEz, implying that it is also relevant where other States are

38 See also N Matz-Lück and J Fuchs, 'The impact of OSPAR on protected area management beyond national jurisdiction: Effective regional cooperation or a network of paper parks? (2014) 49 Marine Policy $155^{-166}$ at pp. 156-157.

39 Next to their obligations under Part XII, States would also be bound by the requirement to pay due regard where other States in exercising their high seas freedoms have designated MPAs.

40 See also MC Ribeiro, 'South Atlantic Perspectives on the Future International Legally Binding Instrument under the LOSC on Conservation and Sustainable Use of ввNJ' (2017) 32 International Journal of Marine and Coastal Law 733-764 at p. 758 (n 107).

LosC, Article 58(3). See also Dispute concerning delimitation of the maritime boundary between Bangladesh and Myanmar in the Bay of Bengal (Bangladesh/Myanmar); Judgment of 14 March 2012 (available at www.itlos.org/fileadmin/itlos/documents/cases/ case_no_16/C16_Judgment_14_03_2012_rev.pdf), para. 475 . 
exercising rights or acting in accordance with their duties in $\mathrm{ABNJ}^{43}$ There would not seem to be a justification for imposing this obligation on the coastal State and not on States carrying out activities in $\mathrm{ABNJ}$ that may affect the rights and duties of the coastal State in its EEZ. This argument is reinforced by the fact that the LOSC imposes a "due regard" obligation in other instances that require balancing the rights of States. ${ }^{44}$ Third, the judgment of the ITLOS in Bangladesh/Myanmar provides support for the view that States carrying out activities in $\mathrm{ABNJ}$ have to have due regard for the rights and duties of coastal States in the EEz. ${ }^{45}$ Finally, Article 194(4) of the LOSC, read in conjunction with Article 194(5), indicates that States designating MPAs in any case have a "due regard" obligation to all other States, including coastal States. ${ }^{46}$

Part VI of the LOSC, in dealing with the rights and freedoms of other States in the waters superjacent to the coastal State's continental shelf, does not employ the term "due regard", but instead provides that the coastal State in exercising its rights "must not infringe or [...] unjustifiable interfere [...] with navigation and other rights and freedoms of other States". ${ }^{47}$ However, the arbitral tribunal in Chagos, in a discussion of the words "unjustifiable interference" contained in Article 194(4) of the LOSC, observed that it considered them "to be functionally equivalent to the obligation to give 'due regard'". 48

43 It may be noted that the chapeau of Article 56 refers to "Rights, jurisdiction and duties of the coastal State in the exclusive economic zone". However, that does not exclude a transboundary component to those rights, jurisdiction and duties (see also, e.g., LOsc, Article 195).

44 For a further discussion see this section, below.

45 In paragraph 475 of the judgment, the Tribunal discusses the situation of concurrent jurisdiction-i.e., one State having rights in the water column and the other in the seabed and subsoil. The Tribunal concludes that in such a situation of concurrent jurisdiction a State "must exercise its rights and perform its duties with due regard to the rights and duties of the other" (Bangladesh/Myanmar (n 41) at para. 475). The Tribunal in the quoted text refers to the situation of concurrent jurisdiction of two coastal States, but it is clear from the context that this finding is also applicable to a situation involving a coastal State and a State carrying out activities in ABNJ. Second, the Tribunal considers a situation of vertical concurrent jurisdiction (overlap of the high seas with the continental shelf or the water column of the EEZ with the continental shelf). However, there is no legally relevant difference with a situation of horizontal concurrent jurisdiction (e.g., the EEZ and an adjacent area of the high seas).

$46 \quad$ For a further corroboration of this point see the text at (nn 47) et seq.

47 LOSC, Article $78(2)$. For a further discussion of the implications of the concept of "unjustifiable interference" see J Mossop, The continental shelf beyond 200 nautical miles: Rights and responsibilities (Oxford University Press, Oxford, 2016), chapter 7.

48 Chagos Marine Protected Area Arbitration (Mauritius v. United Kingdom), Award of 18 March 2015, para. 540; see also Bangladesh/Myanmar (n 41) at para. 475. This view is supported by the commentary of the International Law Commission (ILC) on Article 71 of its 
That standard contained in Article 194(4) also applies to measures taken on the basis of Article 194(5), which provides, as was observed above, a legal basis and in its application may require the designation of MPAS in ABNJ. In the EEZ, the other States mentioned in Article 78(2) are required to give due regard to the rights and duties of the coastal State in relation to its continental shelf under Article 58(3) of the LOSC. The LOSC does not contain a similar "due regard" provision in relation to these other States for the high seas superjacent to the continental shelf. However, Mossop has observed that the existence of such an obligation is evident from the drafting history of the Convention on the Continental Shelf, which provided the basis for the substantive provisions of the continental shelf regime of the Losc. ${ }^{49}$ Article 79, dealing with cables and pipelines on the continental shelf, does employ the concept of "due regard", which is applicable to both the coastal State and other States. ${ }^{50}$

Due regard as a standard for balancing the interest of the international community and the coastal State is also included in Part XI of the LOSC. As a general rule, mineral resource activities "in the Area shall be carried out with reasonable regard for other activities in the marine environment".51 The inclusive term marine environment includes marine areas within national jurisdiction. Article 142 provides that for mineral deposits that straddle the limits between the Area and an area under national jurisdiction mineral resource activities in the Area "shall be conducted with due regard to the rights and legitimate interests" of the coastal State. Article 142 does not impose a similar "due regard" obligation on the coastal State in such a situation. However, Article 137 on the legal status of the Area and its mineral resources would be applicable in this instance, implying a more stringent obligation than due regard. Article 137 provides, among others, that no State shall appropriate any part of the Area or its mineral resources. ${ }^{52}$

1956 Draft Articles on the Law of the Sea, which is the direct precursor to Article 78 of the LOSC and contains the words "unjustifiable interference" (Yearbook of the International Law Commission 1956, Vol. II, p. 299; the relevant text is reproduced below at (n 66).

49 Convention on the Continental Shelf (Geneva, 29 April 1958, in force 1o June 1964) 499 UNTS 312. J Mossop, 'The relationship between the continental shelf regime and a new international instrument for protecting marine biodiversity in areas beyond national jurisdiction' (2018) 75(1) ICES Journal of Marine Science 444-450 at p. 446.

5o Losc, Article 79(5).

$5^{1} \quad$ LOSC, Article 147(1).

52 Chircop, who refers to Article 142 as "one of the most one-sided provisions" of the Convention, seems to consider that Article 137 is not relevant in this context (A Chircop, 'Managing Adjacency: Some Legal Aspects of the Relationship Between the Extended Continental Shelf and the International Seabed Area' (2011) 42 Ocean Development \& International Law 307-316, at p. 312). However, he submits that a customary law obligation 
The LOSC provisions dealing with fish stocks that occur in the EEZ as well as in the adjacent high seas go beyond the requirement of "due regard" that generally controls interactions between coastal States and States carrying out activities in ABNJ. Article 116 of the LOSC, dealing with the right to fish in the high seas, provides that this right is, inter alia, subject to "the rights and duties as well as the interests of coastal States provided for, inter alia, in article 63, paragraph 2, and articles 64 to 67 " of the Losc. ${ }^{53}$ Article 66 gives primary responsibility to the State of origin of anadromous stocks, and Article 67 gives primary responsibility to the relevant coastal State in relation to catadromous stocks. Fishing directed at catadromous stocks is only allowed within the limits of the EEz. ${ }^{54}$ Fishing directed at catadromous stocks beyond the limits of the EEZ is only allowed to avoid "economic dislocation for a State other than the State of origin". ${ }^{55}$ Articles $63(2)$ and 64, dealing respectively with straddling and highly migratory fish stocks, envisage, in different terms, cooperation between the coastal State(s) and States fishing on the high seas. ${ }^{56}$ Articles $63(2)$ and 64 have been further elaborated through Article 7 of the FSA, which deals with the compatibility of conservation and management measures established by the coastal State for the EEZ and those established for the relevant area beyond. ${ }^{57}$ Superficially, the concept of "compatibility" might seem to display similarities with that of "due regard" as elaborated in the award in Chagos. ${ }^{58}$ In both instances, the activities of one State that (may) affect the rights and duties of another State have to be further assessed to establish how adverse effects may be avoided or limited and certain considerations that should be taken into account are listed. However, the nature of the interaction between the States involved is different. Article 7 of the FSA requires, inter alia, that the

for coastal States to consult with the Authority concerning straddling mineral resources may exist (ibid., p. 313).

Article $63(2)$ requires the States concerned to "seek [...] to agree upon the measures necessary for the conservation of these stocks in the [area adjacent to the exclusive economic zone]" in which the straddling stock occurs. Article 64(1) requires the States concerned to "cooperate $[\ldots]$ with a view to ensuring conservation and promoting the objective of optimum utilization of [highly migratory stocks] throughout the region [in which fishing takes place], both within and beyond the exclusive economic zone".

57 For a further discussion of Article 7 of the FSA see, e.g., AG Oude Elferink, 'The Determination of Compatible Conservation and Management Measures for Straddling and Highly Migratory Fish Stocks' (2001) 5 Max Planck Yearbook of United Nations Law $55^{1-607}$.

$5^{8}$ See further text below, at ( $\left.\mathrm{n} 72\right)$ et seq. 
measures for straddling fish stocks and highly migratory fish stocks applicable to the high seas "do not undermine the effectiveness" of measures taken by the coastal State(s) in accordance with Article 61 of the LOSC and States have to agree on compatible measures for both areas. ${ }^{59}$ On the other hand, the requirement to pay "due regard" does not require this level of coordination-a State would in most instances be required to consult with other States, but does not need to agree with other States on what would be proper in regulating an activity ${ }^{60}$ — and entails less deference to the rights and duties of the coastal State.

The concept of "adjacency" could be said to be reflected in Article 63 of the LOSC, which mandates cooperation between the coastal State and States fishing in the adjacent area. ${ }^{61}$ Otherwise, the LosC does not refer to adjacency in the context of addressing the relationship between coastal States and States carrying out activities in ABNJ. ${ }^{62}$ The concept of "respect" that States had advanced during the PrepCom discussions does not feature in the text of the LOSC in the sense that other States in exercising their rights and fulfilling their obligations in ABNJ should respect the rights of the coastal State. ${ }^{63}$

The above overview indicates that under the LOSC the concept of "due regard" provides the general benchmark for addressing the relationship between coastal States and States carrying out activities in ABNJ. It is submitted

$59 \quad$ FSA, Article $7(2)$.

6o Article $7(2)$ of the FSA provides that "coastal States and States fishing on the high seas have a duty to cooperate for the purpose of achieving compatible measures in respect of [the stocks concerned]".

61 It should be realized that the content of the concept as reflected in the LOSC may differ from the specific content which States may want to accord the concept in the context of the ILBI (see also above text at (n 17)).

62 Articles 64, 66 and 67, without employing the terms adjacent or adjacency, also reflect a recognition of the fact that the occurrence of fish stocks within and beyond the EEZ requires addressing the rights and interests of the coastal States by means other than the generally applicable concept of "due regard". At first sight, the designation of MPAs in ABNJ might not seem to detract from the specific regimes set up under Articles 63, 64, 66 and 67 of the LOSC, as such a designation could contribute to the ensuring the conservation of the stocks concerned and also could enhance the conservation status of the stock in the EEz.

63 Three references to the concept of "respect" are included in Article 51, which deals with existing agreements, traditional fishing rights and existing submarine cables in archipelagic waters. In this case the requirement of "respect" is imposed on the coastal State. Article 240 (c) provides that "marine scientific research shall not unjustifiably interfere with other legitimate uses of the sea compatible with this Convention and shall be duly respected in the course of such uses". Article 242(1) requires States to promote cooperation on marine scientific research "in accordance with the principle of respect for sovereignty and jurisdiction". 
that this also requires including this concept in the ILBI as the benchmark for dealing with the relationship between coastal States and other States. A different approach would detract from the jurisdictional framework contained in the LOSC, and would imply a departure from the understanding that the ILBI has to be fully consistent with the LOSC. The concept of "adjacency" only figures in the LOSC in the context of the regime for fisheries. ${ }^{64}$ The concept of "compatibility", which is not included in the LOsc, elaborates on the rights and obligations of States to cooperate in relation of straddling fish stocks and highly migratory fish stocks. The use of these concepts in the context of fisheries management raises the question whether they should and can be applied equally in other contexts. However, even if this were to be the case, recourse to these concepts as a general standard could detract from the current role of "due regard" in addressing the interactions between coastal States and States carrying out activities in ABNJ under the LOSC. The latter argument applies equally to the concept of "respect", which does not figure in the LOSC at all.

To obtain a clearer idea of the implications of the concept of "due regard", this section provides an overview of its content. Due regard and its 'functional equivalent' of "unjustifiable interference" have their origin in the work of the International Law Commission (ILC) and the 1958 United Nations Conference on the Law of the Sea (1958 Conference). ${ }^{65}$ These sources provide little information about the content of these concepts. However, two points may be noted. The ILC in its comment on Article 71 of its draft project for a law of the sea convention stressed the need to weigh the interest involved, observing that:

The case is clearly one of assessment of the relative importance of the interests involved. Interference, even if substantial, with navigation and fishing might, in some cases, be justified. On the other hand, interference even on an insignificant scale would be unjustified if unrelated to

64 See also Dunn et al. who, in advocating the concept of adjacency, only refer to Articles of the LOSC concerned with fisheries (Dunn et al. (n 18) at pp. 3 and 9).

65 The Convention on the High Seas actually uses the concept of "reasonable regard" (Geneva, 29 April 1958, in force 30 September 1962) 450 UNTS 11, Article 2. The equivalent provision of the LOSC uses the concept of "due regard" (LOSC, Article 87(2)). 
reasonably conceived requirements of exploration and exploitation of the continental shelf. 66

The other point of note is that in reply to the criticism that concepts like "unjustifiable interference" were too vague, it was submitted that clarification could be achieved by judicial settlement. As was observed at the 1958 Conference by J.P.A. François, the former ILC rapporteur on the topic of the law of the sea:

Any attempt to codify international law without using such expressions will prove vain. In contentious cases, the meaning will have to be decided by an impartial authority, to which disputes regarding the interpretation of these expressions in specific cases are to be submitted. ${ }^{67}$

Although the assessment that further elaboration of these concepts in a future international agreement would be impossible at present might be overly pessimistic, no such attempt was in any case undertaken during the negotiations of the Losc. However, the dispute settlement mechanisms included in the LOSC have resulted in a significant clarification of the concept of "due regard". In Bangladesh/Myanmar, the ITLOs observed the parties owed each other a "due regard" obligation in exercising their rights and performing their obligations in an area in which one had sovereign rights over the water column and the other over the seabed and subsoil. ${ }^{68}$ Next, the Tribunal observed that:

There are many ways in which the Parties may ensure the discharge of their obligations in this respect, including the conclusion of specific agreements or the establishment of appropriate cooperative arrangements. It is for the Parties to determine the measures that they consider appropriate for this purpose. ${ }^{69}$

66 Yearbook of the International Law Commission 1956, Vol. II, p. 299; see also the statement of the Indian delegate to the same effect (United Nations Conference on the Law of the Sea; Official Records (A/CONF.13/42), Vol. vI, p. 12, para. 9).

67 United Nations Conference on the Law of the Sea; Official Records (A/CONF.13/42), Vol. IV, p. 34, para. 20; to the same effect see also Yearbook of the International Law Commission 1956, Vol. II, p. 299; Official Records (n 66), Vol. VI, p. 12, para. 9).

68 Bangladesh/Myanmar (n 41) at para. 475.

$69 \quad$ Ibid., para. 476 . 
This finding was confirmed by the arbitral tribunal in Bangladesh v. India, in which a similar situation of overlap existed. ${ }^{70}$ The tribunal further added that it was "confident that the Parties will act, both jointly and individually, to ensure that each is able to exercise its rights and perform its duties within this area".71 These pronouncements provide little to no guidance to the parties on how to discharge their obligations, apart from stressing their contractual freedom. Perhaps most significantly, the arbitral tribunal in Bangladesh v. India stressed that these duties are owed jointly and individually. In the absence of agreement on cooperative measures, States are still required to assess how to ensure that due regard is given to the rights and duties of the other State(s). The specific course of action that is the outcome of that assessment would, in the case of disagreement, be open to judicial settlement.

Thus far, the most significant elaboration of the concept of "due regard" has been provided by the arbitral tribunal in Chagos. One of the issues before the tribunal was whether the United Kingdom, in establishing an MPA in the EEZ of the Chagos Archipelago, had given due regard to the fishing rights of Mauritius, as it was required to do under Article 56(2) of the LOSC. In assessing this question, the arbitral tribunal first pointed to the case-specific nature of "due regard", observing that the United Kingdom had "to have such regard for the rights of Mauritius as is called for by the circumstances and by the nature of those rights". ${ }^{72}$ Unsurprisingly, the tribunal did not find:

this formulation [to reflect] any universal rule of conduct. The Convention does not impose a uniform obligation to avoid any impairment of Mauritius' rights; nor does it uniformly permit the United Kingdom to proceed as it wishes, merely noting such rights. ${ }^{73}$

The tribunal subsequently formulated three criteria to arrive at a proper implementation of "due regard":

- Balancing of the rights involved;

- The consideration of alternative approaches; and

- Assessing the need for consultation with the other State concerned. ${ }^{74}$

$70 \quad$ In the Matter of the Bay of Bengal Maritime Boundary (Bangladesh v. India), Award of 7 July 2014 (available at http://www.pcacases.com/web/sendAttach/383), para. 508.

$71 \quad$ Ibid.

72 Chagos (n 48) at para. 519 .

73 Ibid.

74 Ibid. In respect of the last point, the tribunal observed that in most cases "at least some consultation with the rights-holding State" would have been appropriate (ibid.). 
As the reasoning of the tribunal indicates, due regard requires informed decision-making that provides evidence that the rights that are involved are properly identified and weighed. Chagos also indicates that the decision on how to implement due regard rests on the State that is exercising its rights or performs its obligations and does not require the concurrence of the other State concerned.

During the PrepCom, the Pacific small islands developing States in particular have pointed to the specific interests of developing States, including small island developing States, and in that connection have invoked the need for proportionate burden-sharing. ${ }^{75}$ This raises the question how these concepts relate to the concept of "due regard". Paying due regard would require taking into account the rights and obligations of developing States and in that context seeking to avoid disproportionate burden-sharing. At the same time, the concept of "due regard", as is also evident from the discussion of Chagos, could lead to the result that these considerations are not (fully) taken into account. It may be questioned whether that provides an equitable solution to this matter.

\section{Regional Practice in Respect of MPAs in ABNJ}

Four regional frameworks for the protection and preservation of the marine environment have already dealt with the issue of MPAs in ABNJ. ${ }^{76}$ These are the Nouméa, OSPAR, and Barcelona Conventions (South Pacific Ocean, NorthEast Atlantic Ocean and Mediterranean Sea respectively), ${ }^{77}$ and the Hamilton Declaration (Sargasso Sea). ${ }^{78}$ This section first briefly considers the relevant

75 See, e.g., Fiji's Submission (n 20) at para. 27; PSIDS Submission (n 21) at p. 3. For a discussion of the concept of (dis)proportionate burden sharing see e.g. T Scovazzi, R Davis, Q Hanich and A Vrahnos, 'Defining a disproportionate burden in transboundary fisheries: lessons from international law' (2016) 70 Marine Policy 188-191.

76 The extensive experience of the Commission for the Conservation of Antarctic Marine Living Resources in respect of the designation of MPAs in ABNJ is not discussed in this section. Due to the absence of generally recognized coastal States that practice is of limited relevance to the matter that is under consideration in this article.

77 Convention for the Protection of the Natural Resources and Environment of the South Pacific Region (Nouméa, 24 November 1986, in force 18 August 1990, available at http:// www.sprep.org/attachments/Legal/Files_updated_at_2014/NoumeaConvProtocols.pdf); Convention for the Protection of the Marine Environment of the North-East Atlantic (Paris, 22 September 1992, in force 25 March 1998) (1993) 32 International Legal Materials 1072; Convention for the Protection of the Marine Environment and the Coastal Region of the Mediterranean (Barcelona, 10 June 1995, in force 9 July 2004) 1102 UNTS 27.

78 Hamilton Declaration on Collaboration for the Conservation of the Sargasso Sea (adopted on 11 March 2014; available at http://www.sargassoseacommission.org/storage/ 
provisions of the above instruments and relevant practice in relation to these instruments and then provides an assessment in the light of the issue under consideration in this article.

\subsection{The Relevant Regional Practice}

The Nouméa Convention provides that its Convention Area is constituted by the EEzs of the States parties, and in addition also includes the "areas of high seas which are enclosed from all sides by the 200 nautical mile zones" of the Parties. ${ }^{79}$ Article 14 envisages the possibility of designating protected areas in the Convention Area and further provides that "[ $\mathrm{t}]$ he establishment of such areas shall not affect the rights of other Parties or third States under international law". Thus far the States Parties to the Nouméa Convention have not taken any action in relation to the establishment of MPAs in ABNJ.

The Barcelona Convention is applicable to the Mediterranean Sea. ${ }^{80}$ Due to the dimensions of the Mediterranean Sea, it is entirely within 200 nautical miles from the surrounding coasts. However, because several coastal States of the Mediterranean Sea have not yet established a 200-nautical-mile zone, large parts of the water column beyond the territorial sea for the time being remain part of the high seas overlying the continental shelf. The possibility of establishing MPAs in the high seas of the Mediterranean Sea is envisaged under the Protocol Concerning Specially Protected Areas and Biological Diversity in the Mediterranean (SPAMI Protocol), which was adopted together with the revised Barcelona Convention in 1995, and also applies to the high seas areas of the Mediterranean Sea. ${ }^{81}$ The Protocol provides that it is without "prejudice [to] the rights, the present and future claims or legal views of any State relating

documents/Hamilton_Declaration_with_signatures_January_2017.pdf). One could ask whether the Hamilton Declaration itself actually establishes an MPA. That case could be made (see, e.g., Hamilton Declaration, paras 1-3, which recognize the Sargasso Sea's "high ecological and biological significance, its cultural importance and its outstanding universal value", affirm that the guiding principle of the Declaration is the Sargasso Sea's conservation and that to that end the signatories will collaborate in pursuing conservation measures). The Declaration in any case is relevant for the present analysis because of, among others, its identification of actors relevant for its further implementation.

79 Nouméa Convention, Article $2(\mathrm{a})$.

8o Barcelona Convention, Article 1(1). For a discussion of the Barcelona Convention see, e.g., I Papanicolopulu, 'The Mediterranean Sea' in D.R Rothwell, AG Oude Elferink, T Stephens and KN Scott (eds.) The Oxford Handbook of the Law of the Sea (Oxford University Press, Oxford, 2015) 604-625.

81 Protocol Concerning Specially Protected Areas and Biological Diversity in the Mediterranean (SPAMI Protocol) (Barcelona, 10 June 1995, in force 12 December 1999); available at http://rac-spa.org/sites/default/files/protocole_aspdb/protocol_eng.pdf), article $2(1)$. 
to the law of the sea, in particular, the nature and the extent of marine areas [...], as well as the nature and extent of the jurisdiction of the coastal State, the flag State and the port State". ${ }^{22}$ The Protocol makes a distinction between MPAS and Specially Protected Areas of Mediterranean Importance (SPAMIs). Whereas the former may only be designated in areas under coastal State sovereignty or jurisdiction, ${ }^{83}$ the latter may also be situated on the high seas. ${ }^{84} \mathrm{In}$ this case, a proposal to include an area in the list of SPAM Is may be submitted by "by two or more neighbouring Parties" to the Protocol. ${ }^{85}$ The Protocol does not further define the term "neighbouring Parties", but its use in the Protocol suggests that it is intended to refer to States that are adjacent to the area of high seas concerned. ${ }^{86}$

The Pelagos Sanctuary is the only SPAMI that currently is located in part on the high seas. ${ }^{87}$ The Sanctuary has been designated and is jointly managed by France, Italy and Monaco in accordance with the Agreement on the creation of a marine mammal sanctuary in the Mediterranean concluded by these States. ${ }^{88}$ It is partly located in their waters and partly in the high seas area adjacent to these waters. ${ }^{89}$ The Agreement provides that its parties "may invite any other interested State or international organization to accede to the [...] Agreement". ${ }^{90}$

The spatial scope of application of the OSPAR Convention is the North-East Atlantic (Maritime Area) and includes extensive areas of ABNJ. ${ }^{91}$ In this connection, Article 1(a) provides that the Maritime Area includes "the sea beyond and adjacent to the territorial sea under the jurisdiction of the coastal state to the extent recognised by international law". ${ }^{92}$ In 1998, the Contracting Parties to the ospar Convention concluded Annex v to the Convention concerned

\footnotetext{
$82 \quad$ Ibid., Article 2(2).

83 Ibid., Article 5 .

$84 \quad$ Ibid., Article 9(2)(b).

85 Ibid.

86 See ibid., Articles 9(2)(b), 9(2)(c) and 9(3)(a).

$87 \quad$ Further information on the Pelagos Sanctuary is available on the website of the Sanctuary (http://www.sanctuaire-pelagos.org/en/).

88 Agreement on the creation of a marine mammal sanctuary in the Mediterranean (Monaco, 25 November 1999, in force 21 February 2001) 2176 UNTS 247.

89 Ibid., Article 3.

9o Ibid., Article 20.

91 OSPAR Convention, Article 1(a). On OSPAR's designation of MPAs in ABNJ see also, e.g., Matz-Lück and Fuchs (n 38) at pp. 158-162; Molenaar and Oude Elferink (n 31).

92 Emphasis added.
} 
with biodiversity. ${ }^{93}$ Annex v requires the Contracting Parties to "develop means, consistent with international law, for instituting protective, conservation, restorative or precautionary measures related to specific areas or sites or related to particular species or habitats". ${ }^{94}$

Following the adoption of Annex v, the OSPAR Contracting Parties have worked towards the designation of a network of MPAs in their maritime zones and in ABNJ of the Maritime Area. Two OSPAR documents from 2003 set up a framework for the designation of mPAs in the Maritime Area. This concerned OSPAR Recommendation 2003/3 on a Network of Marine Protected Areas ${ }^{95}$ and the 2003 Strategies of the OSPAR Commission for the Protection of the Marine Environment of the North-East Atlantic (OSPAR Strategies). ${ }^{96}$ Recommendation 2003/3 distinguishes between MPAs within national jurisdiction areas and beyond the national jurisdiction of the OSPAR Contracting Parties. ${ }^{97}$ The OSPAR Network of Marine Protected Areas (OSPAR Network) is to consist of MPAS within national jurisdiction, which are reported by the coastal State concerned, and MPAS in ABNJ, which have "been included as a component of the network by the OSPAR Commission". ${ }^{98}$ Recommendation $2003 / 3$ originally only set up a specific procedure in relation to MPAs within national jurisdiction, but was amended in 2010 to include a procedure for including MPAS in ABNJ in the OSPAR Network. ${ }^{99}$ Recommendation 2003/3 as amended provides that each Contracting party is to report MPAs within its national jurisdiction. Any Contracting Party may take the initiative to make a proposal to the OSPAR Commission to include MPAS in ABNJ in the OSPAR Network. ${ }^{100}$ The original osPAR Strategies from 2003 already specified that the OSPAR Commission would be charged with designating MPAs in ABNJ. ${ }^{101}$

93 Annex V on the Protection and Conservation of the Ecosystems and Biological Diversity of the Maritime Area (23 July 1998; in force 30 August 200o); available at https://www .ospar.org/site/assets/files/129o/ospar_convention_e_updated_text_in_2007_no_revs .pdf).

94 Ibid., Article 3(1)(b)(ii) (emphasis provided).

95 OSPAR Recommendation 2003/3 on a Network of Marine Protected Areas (Summary Record OSPAR 2003; OSPAR 03/17/1-E, Annex 9).

962003 Strategies of the OSPAR Commission for the Protection of the Marine Environment of the North-East Atlantic (Summary Record OSPAR 03/17/1-E, Annex 31).

97 OSPAR Recommendation 2003/3 (n 95) at para. 1.1.

$98 \quad$ Ibid., paras 1.1 and 3.1.

99 OSPAR Recommendation 2010/2 (OSPAR 10/23/1, Annex 7).

100 See ibid., paras 2.4-2.9, which contain the relevant amendments.

101 OSPAR Strategies ( $\mathrm{n} 96$ ) at section 4.4. Appendix 4 to the Guidelines for the Identification and Selection of Marine Protected Areas in the ospar Maritime Area contained in OSPAR Agreement 2003/17 as amended in 2007 (available at http://www.ospar.org/ documents? $\mathrm{d}=32398$ ) also make this distinction. Coastal states are requested to comply 
The OSPAR Commission has thus far included seven MPAs in ABNJ within the ospar Network: the Charlie-Gibbs South, Milne Seamount Complex, Altair Seamount High Seas, Antialtair Seamount High Seas, Josephine Seamount High Seas, and MAR North of the Azores High Seas MPAs in 2010, and the Charlie-Gibbs North High Seas MPA in 2012. ${ }^{102}$ Two of the M PAs designated by the OSPAR Commission in 2010 (Charlie-Gibbs South Marine Protected Area; Milne Seamount Complex Marine Protected Area) comprise the water column and seabed, which are both part of ABNJ. The other four areas designated in 2010 only concern the high seas water column superjacent to the continental shelf beyond 200 nautical miles of Portugal. All six decisions provide that they: "shall apply without prejudice to the rights and obligations of coastal States, other States and international organisations in accordance with [the LOSC] and customary international law". ${ }^{103}$

In addition, the preamble of all six decisions recognizes that they do not prejudice the rights of coastal States over their continental shelf. ${ }^{104}$ In the case of the MPAs superjacent to the Portuguese continental shelf, the preamble adds that the procedure for designation is not intended to set a precedent for such MPAs and that future designations "will be decided on a case by case basis". 105 The general safeguarding clause of the 2012 decision on the CharlieGibbs North High Seas MPA, which covers waters superjacent to the continental shelf of Iceland, is identical to that of the six 2010 decisions. ${ }^{106}$ The rights of the coastal State are in addition safeguarded in more specific

with a specific process for nominating MPAs under their jurisdiction. A note to Appendix 4 provides that this process does not "apply to any MPA that is the collective responsibility of all Contracting Parties. In such cases, the OSPAR Commission is responsible for data validation and final approval".

102 OSPAR Decision 2010/2 on the establishment of the Charlie-Gibbs South Marine Protected Area (OSPAR 10/23/1-E, Annex 36); OSPAR Decision 2010/1 on the Establishment of the Milne Seamount Complex Marine Protected Area (ibid., Annex 34); ospar Decision 2010/3 on the Establishment of the Altair Seamount High Seas Marine Protected Area (ibid., Annex 38); OsPar Decision 2010/4 on the Establishment of the Antialtair Seamount High Seas Marine Protected Area (ibid., Annex 40); OsPar Decision 2010/5 on the Establishment of the Josephine Seamount High Seas Marine Protected Area (ibid., Annex 42); OSPar Decision 2010/6 on the Establishment of the MAR North of the Azores High Seas Marine Protected Area (ibid., Annex 44); OSPAR Decision 2012/1 on the establishment of the Charlie-Gibbs North High Seas Marine Protected Area (OSPAR 12/22/1, Annex 6).

103 OSPAR Decisions 2010/1 and 2010/2 (n 102) at para. 2.2; and OSPAR Decisions 2010/3 to 2010/6 (n 102) at para. 2.3.

104 OSPAR Decisions 2010/1 to 2010/6 (n 102) at preamble.

105 OSPAR Decisions 2010/3 to 2010/6 (n 102) at preamble.

106 OSPAR Decision 2012/1 (n 102) at para. 2.3. 
terms in the body of the decision. ${ }^{107}$ The preambular considerations of the 2012 decision are more elaborate on the point of the rights of the coastal State and other states than the 2010 decisions, but essentially confirm that the rights of the coastal State over its continental shelf and other States in the superjacent waters are defined in the LOSC. ${ }^{108}$ The difference in wording between the 2010 and 2012 decisions is likely to be explained by the differences in approach of the coastal States concerned. Portugal has designated the parts of its continental shelf concerned as MPAs, but Iceland has not. ${ }^{109}$

The Hamilton Declaration is an outcome of the work of the Sargasso Sea Alliance, which was led by the Government of Bermuda. It aims to conserve the Sargasso Sea high seas ecosystem. ${ }^{110}$ Currently, the Declaration signatories are principally from North America and the Caribbean, but the Declaration also "[e]ncourages participation by any other interested government or regional economic integration organisation in efforts to conserve the Sargasso Sea ecosystem in accordance with this Declaration"."11 The area of collaboration for the Sargasso Sea is defined as the high seas and the Area as defined in Annex I to the Declaration. It excludes the EEzs of Bermuda and other adjacent coastal States, ${ }^{112}$ and the continental shelf of adjacent States that are overlain by the high seas as defined in Annex I. The preamble of the Declaration indicates that it "is not legally binding and is without prejudice to the existing legal rights and obligations of the Signatories under international law or to the competences of regional and international organisations". The focus of the Declaration is on collaboration to achieve "conservation measures for the Sargasso Sea

\footnotetext{
107 Ibid., para. 2.2.

108 Ibid., preamble.

109 For a further consideration of this point see Matz-Lück and Fuchs (n 38) at pp. 161-162.

110 There are now nine signatory governments-Azores, Bahamas, British Virgin Islands, Canada, Cayman Islands, Monaco, UK and US. For a discussion of the Hamilton Declaration and background information to the Declaration and the Sargasso Sea Alliance see D Freestone and KK Morrison, 'The Signing of the Hamilton Declaration on Collaboration for the Conservation of the Sargasso Sea: A New Paradigm for High Seas Conservation?' (2014) 29 International Journal of Marine and Coastal Law 345362; DF Freestone, 'Governance of Areas beyond National Jurisdiction: An Unfinished Agenda?' in J Barrett and R Barnes (eds), Law of the Sea: UnCLOs as a Living Treaty (British Institute of International and Comparative Law, London, 2016) 231-266.

111 Hamilton Declaration, paragraph 10.

112 According to Freestone and Morrison, the Bermudan EEz was excluded from the area of collaboration at the last minute upon the request of the Government of Bermuda (Freestone and Morrison (n 110) at p. 352).
} 
ecosystem through existing regional and international organizations with relevant competences".113

\subsection{Assessment of the Regional Practice}

The regional practice on the role of coastal States in designating MPAs in ABNJ is limited in scope, implying that one should in any case be careful in drawing general conclusions. The relevant practice makes clear that it is not intended to detract from the jurisdictional framework for the oceans contained in the LOSC and customary international law. Thus, these regional frameworks do not intend to alter the existing balance of rights and obligations between coastal States and States carrying out activities in ABNJ. ${ }^{114}$ At the same time, these frameworks indicate that the current legal regime already allows for dealing with the obligations of States in relation to the establishment of MPAs in ABNJ. Further analysis of the experience in this regard could provide insights in how a future ILBI could enhance the effectiveness of these regional frameworks.

A regional approach to the designation of MPAS in ABNJ in principle implies that the coastal State(s) adjacent to the area involved will be part of the designation process. However, that does not mean that the adjacent coastal State has a different role from other participating States. In this connection, a distinction may be made between the role of different States as defined in the instruments concerned and the role of different States in practice. As regards the former point, only the SPAMI Protocol accords a special role to the coastal States that are adjacent to an area that is being considered for MPA designation. However, the case of the Mediterranean is not typical of the situation of $\mathrm{ABNJ}$, which in principle are situated beyond the full suite of coastal State maritime zones that are permitted under the Losc. Rather, once all Mediterranean coastal States have established an E EZ, any MPA that formerly might have been located in the high seas would be located in a maritime zone of one of the coastal States. The provisions of the SPAMI Protocol in all likelihood are intended to avoid the situation that the relevant coastal State(s) would be faced with the situation that there would be MPAs in their maritime zones on whose designation they had not had the final say. ${ }^{115}$

\footnotetext{
113 Hamilton Declaration, paras 3 and 8. For a discussion of initiatives in this respect see Freestone and Morrison, ibid., at pp. 347-349.

114 Most of the States involved in this regional practice are coastal States. However, not all of them are always coastal States that are adjacent to the MPA being designated.

115 See in particular the way in which Article 9 of the SPAM I Protocol has been drafted. It could be asked whether the Mediterranean experience might serve as a precedent in relation to high seas enclaves of limited dimensions. Two arguments indicate that this may not be the case. First, these high seas enclaves are beyond the outer limits of the EEz
} 
It has been suggested that the practice under the OSPAR Convention provides evidence of according a special position to coastal states where the high seas overlap with their continental shelf beyond 200 nautical miles. ${ }^{116}$ As is submitted by Ribeiro: "as demonstrated by the practice of OSPAR Contracting Parties, it is difficult to conceive of the designation of high seas MPAs without the $[\ldots]$ consent" of these coastal States. ${ }^{117}$ However, on closer consideration, the sources on which she relies do not support that conclusion. First, she submits that this practice implies a recognition that the rights of the coastal State over its continental shelf cannot be violated in such cases of overlap. ${ }^{118}$ The OSPAR decision to which she refers to substantiate this argument provides that it "does not in any way prejudice the sovereign rights and obligations of the coastal State over the continental shelf in accordance with [the LOSC]".19 In other words, the decision confirms the jurisdictional framework contained in the LOSC. States cooperating at the regional level can designate an MPA in the high seas, leaving the rights of the coastal State over the continental shelf unaffected.

Moreover, as was set out above, in this case a mutual "due regard" requirement is applicable under the Losc. This "due regard" requirement is part and parcel of the rights and obligations of the coastal State in relation to its continental shelf to which the decision refers. In support of the assertion that the designation of an MPA in the water column of the high seas overlying the continental shelf of a coastal State requires its consent, Ribeiro refers to three designations by OSPAR and a report prepared by the OSPAR Commission in 2014. ${ }^{120}$ As was discussed above, all OSPAR decisions on the designation of MPAS in ABNJ state that they are without prejudice to the rights and obligations

and the continental shelf, whereas the high seas in the Mediterranean is in its totality within 200 nautical miles of the coast. Second, in the negotiation of the FSA, the matter of high seas enclaves was also considered, resulting in Articles 15 and 16 of the FSA. These articles do little to develop the legal framework the Agreement otherwise establishes (see also M Hayashi, 'The 1995 Agreement on Straddling Fish Stocks and Highly Migratory Fish Stocks: Significance for the Law of the Sea Convention' (1996) 26 Ocean and Coastal Development 51-69, at pp. 64-65; E Hey, 'Global Fisheries Regulations in the First Half of the 199os' (1996) 11 International Journal of Marine and Coastal Law 459-490, at pp. 474-475). However, this does not exclude that the coastal States de facto would have more influence in the case of high seas enclaves than $\mathrm{ABNJ}$ in general even if the legal regime would be the same.

116 Ribeiro (n 40) at pp. $75^{6-757 .}$

117 Ibid., p. 757.

118 Ibid.

119 As quoted in ibid. at (n 101).

120 See (n 102). 
of coastal States and other States as defined in the LOSC and customary international law. The decisions have been adopted by the OSPAR Commission and the decision-making process does not accord a privileged position to specific coastal States. ${ }^{121}$ The OSPAR Status Report's discussion of the designation of MPAS in ABNJ in the Maritime Area does not contain any indication that this requires the consent of a coastal State having a continental shelf beyond 200 nautical miles. ${ }^{122}$

\section{$6 \quad$ Conclusions}

The LOSC and the СвD indicate that the primary responsibility for dealing with MPAS in ABNJ rests on States under whose jurisdiction or control activities affecting biodiversity in ABNJ take place. Cooperation is the key element in this respect. These provisions do not suggest the existence of a specific competence for adjacent coastal State in dealing with MPAs in ABNJ.

Four concepts have been advanced at the PrepCom for addressing the role of coastal States and other States in the designation of MPAS in ABNJ: due regard, adjacency, compatibility, and respect for coastal State sovereignty or sovereign rights. In proposing specific concepts to the PrepCom, little to no elaboration of the implications of these concepts has thus far been provided. To further assess the implications of these concepts, the present article has considered how the LOSC and other relevant instruments have or have not relied on them in addressing the interaction between coastal States and States carrying out activities in ABNJ. The determination of existing legal relationships in negotiating an agreement that further elaborates the applicable legal framework provides a logical point of departure, as it indicates how further elaboration can be best accomplished, while building on existing frameworks. Moreover, the negotiations at the intergovernmental conference and its outcome are required to be fully consistent with the LOSC. This requirement would not be met if the ILBI would adopt an approach that does not take into account concepts contained

121 Article 13(1) of the OSPAR Convention provides that: "Decisions and recommendations [of the ospar Commission] shall be adopted by unanimous vote of the Contracting Parties. Should unanimity not be attainable, and unless otherwise provided in the Convention, the Commission may nonetheless adopt decisions or recommendations by a threequarters majority vote of the Contracting Parties".

122 See OSPAR Commission, 2014 Status Report on the OSPAR Network of Marine Protected Areas (compiled by Germany for OSPAR, 2015), pp. 18-21. However, the process leading up to the designation of MPAS in ABNJ by the OSPAR Commission in large part may have been driven by the wish to maintain consensus (see Matz-Lück and Fuchs (n 38$)$ at p. 162). 
in the LOSC or would change the legal relationship between coastal States and States carrying out activities in ABNJ as defined in the LOSC.

The present analysis of the LOSC points out that it does not contain the requirement of "respect for coastal State sovereignty or coastal State rights". The concept of "adjacency" is only employed in the context of fisheries and has been elaborated through the concept of "compatibility" in the context of the FSA, which has a different connotation from the concept of "due regard". Due regard is the concept that is generally applicable between coastal States and States carrying out activities in ABNJ under the LOSC. In light of the agreement that the ILBI is to be fully consistent with the LOSC, this conclusion indicates that due regard should also be the main concept for regulating the relationships between coastal States and States carrying out activities in ABNJ under the ILBI. As is apparent from the above discussion, due regard is a "two-way street". Coastal States are required to give due regard to the rights and obligations of States carrying out activities in ABNJ-also where this concerns measures to protect the marine environment-and vice-versa. ${ }^{123}$ The analysis of the (limited) regional practice in relation to the establishment of MPAS in ABNJ indicates that the States concerned recognize that the LOSC and customary international law provide the jurisdictional framework for this exercise. In other words, it is accepted that due regard is part of the jurisdictional framework for dealing with the interactions between coastal States and States carrying out activities in ABNJ.

If the central place of "due regard" in the Losc scheme for dealing with the interactions between coastal States and States carrying out activities in ABNJ will be included in an ILBI, it should be considered whether and how that concept could be further elaborated. ${ }^{24}$ As was set out above, when the concept was introduced in a law of the sea context in the 1950s, it was argued that further clarification could be attained through third-party dispute settlement. Indeed, significant clarification has been achieved through the recent award in Chagos. However, arguments against continued reliance on that approach,

123 See also Ribeiro (n 40) at pp. $75^{8-759 .}$

124 As long ago as 2008 Treves submitted that the concept of "due regard" should be included in a future instrument dealing with $\mathrm{ABNJ}$, indicating that it could be elaborated along the following lines: "It should state specific criteria for ensuring coexistence of different activities, and, if necessary, establish priorities, or mechanisms for dealing with conflicts. If a plurality of machineries is to be set up, each regime should make provision for the possibility of efficient contacts and cooperation between them" (T Treves, 'Principles and Objectives of the Legal Regime Governing Areas Beyond National Jurisdiction', in EJ Molenaar and AG Oude Elferink (eds), The International Legal Regime of Areas beyond National Jurisdiction: Current and Future Developments (Martinus Nijhoff Publishers, Leiden, 2010) 7-25 at p. 22; see also Mossop (n 49) at p. 449). 
and which instead plead for dealing with the operationalization of due regard in the ILBI itself, are that the designation and management of MPAS in ABNJ may quite often require recourse to due regard. In those circumstances, the option of clarification by resort to compulsory dispute settlement may prove to be ineffective, due to its adversarial nature, which may complicate future cooperation, the costs involved, and the unwillingness to litigate. If it were found to be impossible to elaborate the concept of "due regard" in the ILBI, it could alternatively be envisaged to provide for elaboration through the institutional framework that may be set up by the ILBI. One point that might seem to require attention is the specific situation of developing States. To account for their limited capabilities, the ILBI could, for instance, explicitly provide that one aspect of due regard would be to achieve proportionate burden-sharing between developed and developing States.

It may finally be asked if there could be any justification for replacing the generally applicable concept of "due regard" by the concept of "adjacency" (or "compatibility") that only is relevant to the fisheries sector. The article by Dunn et al., which makes a strong case for adjacency, submits in this respect that "extending the rights of coastal States" by reference to adjacency "would likely result in better stewardship of th[e] resources [concerned] given their interest in protecting the biodiversity and ecosystems within their EEZ".125 It is questionable whether this is really the case. The record of coastal States in managing their maritime zones is far from perfect from an environmental perspective and coastal States may also be tempted to accord priority to resource development in their own maritime zones instead of protecting biodiversity (and the marine environment) in ABNJ. The experience in the OSPAR Commission is a case in point that a coastal State may be hesitant to accept an MPA proposal that has received broad support at the regional level. Prioritizing coastal State rights through the concept of "adjacency" can also be expected to lead to a push against international review mechanisms to assess the effectiveness of MPAs in ABNJ for which adjacency would be relevant. Such a push would be in line with the resistance of coastal States to international review of their compliance with international obligations in managing their maritime zones. ${ }^{126}$ As was argued above, an alternative to relying on the concept of "adjacency" to reflect the ideas of oceanographic and ecological connectivity could be the adaptation of the concept of "Range State" included in the cMS to fit the

125 Dunn et al. (n 17) at p. 9.

126 See Treves (n 124) at pp. 8, 11-12. 
circumstances of MPA management in ABNJ. ${ }^{127}$ That concept could operate in a framework that also includes an operationalized "due regard" principle.

Effective protection of marine biodiversity and the marine environment is likely to often require transboundary cooperation. At a conceptual level "due regard" is more in line with this requirement than "adjacency". ${ }^{128}$ Adjacency as espoused at the PrepCom signals a priority of coastal State interests. On the other hand, the two-way street requirement of "due regard", which is both applicable to coastal States and to States carrying out activities in ABNJ, expresses the need for complementarity and integration of measures across jurisdictions.

127 See (n 17).

128 At the same time, the difference between due regard and adjacency may be limited in practice. In most regional contexts, most of the participating States are likely to be States with maritime zones that are adjacent to the ABNJ of the area of application of the relevant regional organization. In addition, as the discussion of the practice in the OSPAR Commission also illustrates, the wish to keep all parties on board may be an important consideration in looking for a compromise solution. 